\title{
Why International Trusteeship Fails: The Politics of External Authority in Areas of Limited Statehood
}

\author{
DAVID A. LAKE* and CHRISTOPHER J. FARISS**
}

\begin{abstract}
International trusteeship is widely touted as a solution to the problem of failed states, an extreme form of limited statehood. Current theories of legitimacy and statebuilding suggest that trusteeships should produce more capable states. These theories, however, fail to take into account the selfinterest and political strategies available to trustees and politicians within new states. We pose a more political model of statebuilding by the international community, the trustee, and national politicians that predicts that trusteeship will fail to produce states with greater capacity. We test for the effects of trusteeship on state capacity, measured by service provision, by creating a matched sample of countries. We find that there is no evidence that states under trusteeship develop greater capacity leading to better provision of public goods than comparable states not under trusteeship. Would-be statebuilders must be more aware of the political incentives of all parties involved in the process.
\end{abstract}

International trusteeship is widely touted today as a solution to the problem of failed states, an extreme form of limited statehood. Yet trusteeship seldom succeeds in building more capable states. Why? The failure of trustees to solve state failures should, perhaps, not be a surprise. Strong, capable states in Europe developed over centuries in unique local conditions. Many competitors failed along the way in a winnowing process that went from nearly 5,000 political units in 990 A.D. to 35 today (Spruyt 1994; Tilly 1990). States also do not fail by accident or without reason. Typically, they have dysfunctional political systems in which leaders have incentives to extract too much from society and strong private actors, often clans or other lineage groups, that block the consolidation of public authority at the center (Acemoglu and Robinson 2012; Goldstone et al. 2000; Rotberg 2004). Statebuilding is a huge and complex task. There is no "state in a box" that can be purchased abroad and assembled at home with easy-tofollow instructions printed in multiple languages.

The task of statebuilding, however, is undermined by current practice that employs an essentially naïve model of politics. In this model, national political leaders, the trustee, and the international community are all

*University of California, San Diego

**Pennsylvania State University

Governance: An International Journal of Policy, Administration, and Institutions, Vol. 27, No. 4, October 2014 (pp. 569-587).

(c) 2014 Wiley Periodicals, Inc.

doi:10.1111/gove.12066 
assumed to build state capacity as their only or certainly their primary goal. We develop a more political model with more realistic assumptions about the policy preferences of these central actors. National leaders want to survive politically and to consolidate their political support coalitions. Unless the national leader happens to share policy preferences with the average citizen, greater state capacity necessarily implies the enactment of "biased" policies. Trustees want more capable states but also states that will enact policies they prefer. When the policy preferences of the trustee and the average citizen diverge, as will almost certainly be the case, the trustee will support a national leader who shares its goals, not those of the population. Thus, there is a trade-off between states that are legitimate in the eyes of their people and states that are "loyal" to the trustee. The greater the divergence between the policy preferences of the trustee and the average citizen, the greater the aid the selected leader will extract from the trustee and the larger the proportion of that aid he will divert to his coalition, with the acquiescence and possible support of the trustee. Finally, the international community wants more capable states but also to sustain the principle of Westphalian sovereignty, which limits the rights of others to intervene in the internal affairs of states-even failed ones. This trade-off results in trusteeships that are duly authorized and legitimate in terms of the international community but limited in scope and duration. With the trustee and the national leaders knowing these limits, both seek to consolidate the support coalition as quickly as possible. Taken together, the interactions of these self-interested political actors are likely to produce unaccountable, illegitimate, and undemocratic regimes without significantly greater state capacity than before the trusteeship. The effect is magnified when the tasks undertaken in statebuilding are complex and poorly institutionalized, as is almost always the case at the failed state end of the statehood continuum. In failing to anticipate these political incentives, "trusteeship failure" was the almost inevitable result of the two most recent U.S. statebuilding efforts in Iraq and Afghanistan. The only times trusteeships are likely to be successful are when the interests of the trustee and average citizen coincide.

We conduct a test of trusteeship and state capacity since 1990, when modern trusteeships first began with some frequency. The presence of a United Nations peacekeeping mission is our proxy for internationally approved trusteeship. We develop a latent variable measure of state capacity and, using a matched sample of states with and without trusteeships, find no effect of trusteeship on state capacity. The results support the political model we develop.

The first part of the current article investigates the concept of trusteeship, and the second part discusses the problem of building state capacity. We then turn to the current practice of international trusteeship and the political theory that appears to underlie it. The fourth part presents our political model of trusteeship that predicts little to no effect on state capacity. The fifth part investigates the relationship between United 
Nations peacekeepingmissions and state capacity. Drawing on the model and empirical results, the conclusion summarizes the argument via three dilemmas of contemporary statebuilding.

\section{What Is International Trusteeship?}

When state authority unravels, the international community has increasingly turned to an international trustee to govern in the state's stead (Bain 2003; Fearon and Laitin 2004; Krasner 2004). This is true both when state authority evaporates, as in Somalia, and when it is abused, as in the case of Serbia's rule over its (now former) province of Kosovo. In the contemporary era, trusteeship is possible only when the subject state cannot or will not exercise authority in a responsible manner. However, states that abuse their sovereignty to threaten or attack other states may, in cases of regime change, also lose the right to control their own affairs, as in Afghanistan and Iraq. These are hardly ineffective states-otherwise, it is difficult to see how they might threaten international peace and security. Nonetheless, we can regard the occupying powers, principally the United States and, in the case of Afghanistan, some Europeans, as trustees as their goal is to create a new regime and restore at least partial sovereignty to the states.

Trustees are sets of states that take direct responsibility for exercising authority in another state on a temporary basis. The trustee is commonly delegated this responsibility by an international organization, a process of legitimation that we discuss below. But trustees have, especially in the past, appointed themselves to assume the sovereignty of another state, especially in the case of occupying powers.

Modern trusteeships are similar to, but different from, colonialism and earlier modes of trusteeship enacted under the mandates of the League of Nations and the strategic trusteeships under the United Nations. In these earlier forms, the sovereignty of the preexisting governance structure was not recognized and the subject people were regarded as unprepared for statehood; they were, therefore, placed under the tutelage of the trustee for their own "protection." Although League of Nations and United Nations trusts were not intended to be permanent, ultimate authority over the subordinate was transferred to the trustee, meaning that sovereignty was vested in the trustee and the relationships were expected to last for extended periods as the subject peoples were educated and "uplifted" to the standard of civilization deemed necessary to assume an equal place in the society of states.

Today's trusteeships, often called neo-trusteeships, assume that the sovereignty of the state is not overturned but simply suspended while a new state is formed that can assume its responsibilities at home and abroad (Fearon and Laitin 2004; Krasner 2004). Since the Cold War, almost all trustees have been authorized by the United Nations. Though these are U.N. missions, they are led by states that choose to commit resources to 
rebuilding other states. In most cases, the lead states bring their proposed intervention to the United Nations for approval, rather than being asked by the Secretary General to take on this responsibility. As authorized by the United Nations, trustees are granted only limited rights over the subordinate, with the authority of the trustee restricted to certain policy or geographic areas. Unlike in colonial relationships, authority is not vested in the trustee but regulated by the international community. For this reason, neo-trusteeship is only likely to arise in extreme cases of limited or abused sovereignty.

\section{Building State Capacity}

Max Weber $(1948,78)$ famously defined the state as "a human community that (successfully) claims the monopoly of the legitimate use of physical force within a given territory." Countries of limited statehood, in turn, lack authority and, especially, a monopoly on the legitimate use of violence throughout their territory (Krasner and Risse 2014). Building state capacity therefore requires the reconstruction of the state's monopoly of violence, suppression of other violence-wielding groups, and equally reconstituting the legitimacy of that monopoly. As we know from the literature on civil war termination, rebuilding a state's monopoly of force can be quite difficult in the absence of total victory (Walter 1997). The disarming or merging of forces can leave groups vulnerable, hesitant to negotiate, and reluctant to implement agreements once reached. Most important, with coercion being their primary political instrument, disarming or merging forces implies changing the balance of power between the groups that existed at the time of agreement. This fatally undermines the credibility of any peace agreement. If one or the other party is weakened by disarming, then the stronger party will have an incentive to violate the agreement in the future; fearing this, the weaker party will refuse the settlement. In states that have withered sufficiently to warrant an international trustee, conditions close to civil war or civil war itself likely exist. Thus, reconstructing the monopoly of force is a general problem for statebuilding. Without denying its importance, this problem of rebuilding the state's monopoly of violence is relatively well understood-if difficult to resolve.

Even tougher, however, is rebuilding the legitimacy of the state, the other side of the coin of state capacity. Typically, by the time a trustee becomes involved, the old state has failed and the political community has been torn apart by violence or the fear of violence. Loyalty to the state, especially if it is controlled or dominated by one group, has evaporated. The political differences that led to limited statehood must be accommodated by changing the existing institutions, but there is no foundation on which to build new institutions. The same holds in occupied states where the previous regime has been overthrown; if the object is to change a regime that is threatening others, the constituency for that regime must be 
changed as well; otherwise, any new leader is likely to act in ways similar to the old leader. In the anarchy that exists in failed states, trustees face the enormously difficult task of rebuilding legitimacy in an environment of fear and animosity. Legitimacy, though central to nearly all political relationships, has been largely ignored in the statebuilding literature (for an exception, see Paris and Sisk 2009, 9). Yet restoring the legitimacy of the state's monopoly of violence is key to building state capacity.

As Weber (1978) recognized, the sources of legitimacy for the state are manifold and complex, resting possibly on the personal charisma of a leader, tradition (institutionalized charisma), or religion (divine right). In the modern age, he argued, legitimacy rested on formal-legal norms, embodied in the bureaucratic state. This view retains considerable sway among legitimate states and the international community. The problem, however, is that we do not have good theories of how to build legitimacy when it has evaporated in failed states. Drawing on the formal-legal approach, the implicit assumption in much of the statebuilding literature is that convening some type of constitutional convention and passing a new basic law will automatically, or at least without great difficulty, legitimate a new government (Lake 2010a, 2010b). Yet a formal-legal approach suffers from the same problem as other explanations of legitimacy, as law rests on established authority that is itself legitimate. When the authority of the state has evaporated, law does not have any special status. What then legitimates the state? Critically for this volume, how does the legitimacy of the trustee affect the rebuilding of the legitimacy of the state?

\section{The State of the Art on the Art of Statebuilding}

Current theory and practice seek to rebuild states on inclusive, democratic, and market-oriented principles under the temporary tutelage of an international trustee. Since at least 1990, there have been two major components of statebuilding policy (Paris 2004). First, as soon as practicable after the end of hostilities, the principal communities are typically brought together under the auspices of an external power(s) in a constitutional convention composed of all stakeholders within the country, excluding only those responsible for atrocities or who represent an overthrown faction (e.g., the Taliban in Afghanistan). This convention is charged with writing inclusive rules of political participation and creating a new structure of democratic politics tailored to the unique circumstances of the country. Once the constitution is ratified, internationally monitored elections are quickly held. In all cases that did not immediately dissolve into renewed fighting, this process ended in elections in two years on average (Paris 2004, 19). Second, the nascent state is encouraged to implement far-reaching market-oriented economic reforms. Along with political liberalization, state builders seek to implement the Washington Consensus 
on economic policy, including reducing barriers to international trade and investment and stimulating private enterprise (Barbara 2008; Paris 2004, 19).

Underlying the theory and practice of statebuilding is a classic liberal conception of the state (Lake 2010b). Four tenets of liberalism are important and fit together into an integrated strategy. Democracy legitimates states by (1) promoting deliberation by citizens in a public sphere, (2) ensuring government responsiveness to citizen demands and desires, and (3) being procedurally fair. In addition, liberal economic policies are understood to both maximize social welfare, and thereby build legitimacy for the state, and constrain the state in ways that help preserve democracy over the long term. ${ }^{1}$ Current policy thus rests on a formal-legal or institutional conception of legitimacy. Getting the institutions "right" means grounding rules of political participation in a basic law drawn up by a broad-based conclave of stakeholders and then holding free and fair elections. The resulting institutions then confer legitimacy on duly elected officials, who subsequently govern fairly under the threat of replacement in future elections.

The role of the trustee in this process of reform is to facilitate the transition to a new, more legitimate regime by providing neutral "peacekeeping" services that ensure a level playing field for antagonistic groups. By bringing external resources to bear, the trustee is expected to create the "political space" in which rival groups can resolve differences. In addition, and perhaps even more important, the trustee can credibly commit to the creation of a specific political order and its attendant governance structures as negotiated by the parties themselves. By committing to the preservation of a specific political order, the trustee can fix expectations around which social order congeals, solving the problem of potential cycling between alternatives (Lake 2010a). The trustee also coordinates foreign aid to rebuild the country's economic infrastructure and political institutions. By helping society and the state "back on their feet," the trustee encourages buy-in from antagonistic groups.

Trustees must themselves be legitimate (Krasner and Risse 2014); otherwise, the political order they oversee will be tainted by "original sin." If regarded as illegitimate, not only will society resist efforts of the trustee to facilitate a new social order, but also any state created by that trustee will be likewise suspect. The legitimacy of the trustee, therefore, is understood to be crucial to the success of the statebuilding effort. Current efforts to legitimate external actors have focused on gaining international approval through multilateral consent to the intervention (Sending 2009). The primary idea is that approval by some multilateral body confers authority on a state or coalition to serve as a temporary trustee (Chesterman 2004; Parker 2003). This is why, since the end of the Cold War unlocked action in the Security Council, virtually all trustees have been appointed by the United Nations. This international approval is assumed to legitimate the trustee in the eyes of the subject population. Like the rebuilt state, the 
legitimacy of the trustee rests on a formal-legal conception, in this case with the international community conferring lawful status on the trustee. Yet there is no reason to expect that international approval of the trustee will directly translate into approval of the trustee by the local population. This is, as we argue below, one of the great flaws in current theories of statebuilding.

Together, these effects suggest that countries subject to trusteeship should enjoy, all else equal, higher levels of state capacity. This is the fervent expectation of policymakers who devote considerable blood and treasure to this end. Legitimate states, governing through participatory institutions with the support of the population, will have greater capacity to govern more effectively. In short, they will have more "statehood" (Krasner and Risse 2014).

Yet this approach to statebuilding is politically naïve. It implicitly assumes that all parties involved in the process possess largely selfless motives in enhancing statehood, stability, and prosperity. National political leaders put "country first" over their narrow partisan needs-even over their political or personal survival. Most important, it is assumed that they accept and live within new, more participatory political institutions, rather than subvert them for their own political ends. Although we do not doubt that there are some true democrats in the world, not all leaders are of this type. Equally, trustees are assumed to value state capacity in their charges above all else. Yet, given that serving as a trustee is costly, only states with "interests" in the failed state are likely to volunteer. There may be some truly other-regarding states willing to take on trusteeships, but it is unlikely that all states who step forward for statebuilding missions are so magnanimous. A more political model of statebuilding leads to very different expectations for the effects of trusteeship on state capacity.

\section{The Politics of Statebuilding}

A political model of externally led statebuilding requires at least three actors: national political leaders, trustees, and the international community. ${ }^{2}$ The political preferences of the local society as a whole are also important, especially in determining whether the trustee and its policies are regarded as legitimate. It is the interaction of the three actors, along with the gap between the policy preferences of the population and the trustee, that determines the success of statebuilding efforts.

Political leaders seek their own survival and, contingent on retaining office, to redistribute wealth and other benefits to themselves and their political coalition (Bueno de Mesquita et al. 2003). In failed states, "natural" political leaders able to unite the country are typically rare. Rather, in the chaos of a failed state, national political leaders are not born but are "manufactured" or selected from among the set of potential leaders by the trustee. Successful leaders will generally have two qualities. Under more participatory institutions, the new leader will be the person 
least objectionable to all parties involved. This may imply the selection of a leader close to the "median voter" or average citizen in society. Almost certainly, however, the new leader will lack a strong and independent base of support. Contenders with their own committed supporters will likely be blocked by rivals. With the acquiescence of all critical parties, but the fervent support of none, the new leader will need to build his own coalition to sustain himself in office. Being the least objectionable candidate is a fragile position, stable only if renewed fighting or anarchy is worse for all parties.

With the trustee playing an important role in the selection process, the new leader must also be acceptable to the trustee and, indirectly, the international community. Because an important job of the new leader will be interacting with the trustee and soliciting international aid, he must be someone the trustee can "work with" in the statebuilding process. This implies that the new leader will have political preferences similar to those of the trustee or, at least, be willing to compromise his own principles to obtain office. The leader will be-at least in part—the trustee's agent in the capital.

Given these characteristics, we can expect the new leader to use his position as intermediary with the trustee to direct foreign aid to his political coalition. Political institutions, in turn, condition the nature of this coalition (Bueno de Mesquita et al. 2003). If the new leader is truly committed to democracy or expects the trustee to support democratic institutions over the long run, he will distribute aid broadly to gain the support of the largest number of voters. In doing so, the leader will supply public goods to create legitimacy for himself and will work to produce greater state capacity to deliver future goods to his constituents. If the leader is not a democrat or does not expect democracy to persist, he will target aid more narrowly to his core supporters, shifting the basket of policies to "private goods." Overall, his regime will be less legitimate to the average citizen and state capacity will be reduced.

International trustees seek greater state capacity and to direct that capacity, at least in part, to their own ends. Trustees-even when authorized by an international body-are self-interested actors. Governing another state, even on a temporary basis, is costly. In insecure environments, troops must be deployed, often for extended periods of time; public services must be provided even though the society lacks the capacity either through poverty or inadequate institutions to pay for them. Nonetheless, trustees have an interest in promoting state capacity as long as that capacity is used in ways they find acceptable. To the extent that the trustee has interests in the country, the new leader must be willing to work with or, more positively, ally with the trustee on issues of concern. An existential interest in political stability will provide some incentive for a trustee to lead a statebuilding effort, but it is specific security or economic benefits to the trustee that will more typically motivate its efforts to build state capacity. 
The trustee may also desire legitimacy for itself, which makes the tasks of governance during the reform period more manageable, or to facilitate its influence with the leader over the long term. Although trustees may be sanctioned by some multilateral institution, this need not legitimate a trustee in the eyes of the public over whom it assumes temporary rule. As a consequence, the trustee will try to "buy" (output) legitimacy by providing public services directly, especially in the early stages of statebuilding, or through aid to the regime, which then provides those services indirectly. The more distant the policies preferred by the trustee are from those of the average citizen, the greater the aid the trustee must provide to gain the same amount of legitimacy. Although the legitimacy of the trustee is important, the effort expended to acquire legitimacy-and the degree of legitimacy so acquired-is actually part of a bargaining process between the trustee, the leader, and the target society.

This implies that the trustee will support the potential leader who either supports its values and goals or is most easily induced by the promise of aid to support its interests. If the trustee's interests are shared by the average citizen, the number of candidates who align with the trustee's interests will be large and any leader selected by the broad population is likely to support its goals. In this case, the trustee will be supportive of democracy and the leader will invest the aid received in ways that produce public goods, greater legitimacy for the regime and the trustee, and greater state capacity. If the average citizen does not share the trustee's goals, however, neither the trustee nor the favored candidate can govern democratically. Although the trustee may continue to espouse broad-based political participation and prefer that the leader invest aid broadly to build a large coalition, both the trustee and the leader will diverge from this ideal, build a narrow coalition, subvert democracy, govern illegitimately, and fail to produce greater state capacity.

When the trustee's preferred policies are far from those of the average citizen, the number of candidates acceptable to the domestic factions and the trustee is likely to be small. The smaller this set, the more leverage any acceptable candidate has over the trustee, the more aid he can extract from the international community, and the more aid he can direct to his own support coalition. In this way, the trustee will be complicit in subverting democracy and the leader's political corruption. In wanting to bolster support for its preferred leader, and its own legitimacy, the trustee will increase aid willingly despite its antidemocratic diversion. Thus, the greater the interests of the trustee in the failed state, and the more those interests diverge from the population of that state, the less participatory will be the new regime, the less legitimate will be the state and trustee, and the less capacity the state will develop.

Finally, the international community has an interest in building state capacity, but it also desires to preserve the principle of Westphalian sovereignty and the norm of nonintervention in the internal affairs of states. Embedding trusteeship in a multilateral body constrains the potential for 
opportunism by the trustee. Given that trustees typically have interests in the target country, international oversight limits the scope and nature of the mission and permits other states to monitor the trustee's actions. When other states can potentially revoke their approval, this can be a powerful means of controlling agency slack by the trustee. On the other hand, Westphalian sovereignty is a political project rather than an internalized international norm (Krasner 1999). Countries and especially those with limited statehood support principles of Westphalian sovereignty to bolster their own status at home and abroad; by collective support for the principle of sovereignty, weak states make both challenges to the regime at home and external intervention in their affairs less likely (Jackson 1990). Given the general desire to protect the principle, states are reluctant to authorize a trustee to assume the sovereignty of another member of the international community. As a result, international trusteeship will be tolerated only in the most dire cases when the state has clearly failed or poses a significant danger to the international community.

The competing goals of building capable states but preserving Westphalian sovereignty create deep ambivalence within the international community that is, in most cases, resolved by authorizing neotrusteeships of limited scope and duration, thus limiting the choices of the new leader and the trustee. Knowing that its role must be limited, the trustee will seek to consolidate power quickly behind its preferred candidate. Unless its interests and those of the average citizen are closely aligned, this requires deemphasizing democratization and acquiescence in the manipulation of aid by its preferred leader. Time is of the essence, as the old canard goes, and the trustee cannot wait for the regime to consolidate itself "naturally." Knowing that the trustee will not be present to support democracy over the long run, the leader will also divert aid to a narrow coalition to consolidate his support. In seeking to maintain the principle of sovereignty, the international community undercuts democracy and economic reform, reduces the legitimacy of the trustee and-in turn-the state, thus undermining the state capacity it is attempting to build. These effects are likely magnified when the statebuilding task is complex and poorly institutionalized (Krasner and Risse 2014). In such cases, monitoring and overseeing the trustee, national leaders, and the diversion of aid will be particularly difficult, undermining further the building of state capacity.

The net effect of these self-interested actions by national leaders, trustees, and the international community is to bolster the political position of new leaders but not necessarily to enhance state capacity. In this more political model of statebuilding, trustees are likely to have little to no effect, on average, on state capacity. In both Iraq and Afghanistan, where they have intense interests in who governs, the United States has backed sympathetic, pro-Western but corrupt leaders who have rigged elections and diverted aid to their supporters. The result is that the U.S. role is regarded as illegitimate by many in Iraqi and Afghani society, who urge a 
rapid withdrawal of forces, and the presence of only weak, incapable states propped up by the promise of continuing foreign aid. ${ }^{3}$ In the case of the Karzai regime in Afghanistan, it is still not able to enforce its writ in many regions of the country, it is highly corrupt with significant U.S. aid diverted to the president's family, and the Taliban remains a potent political force. Yet, the United States is being pressed and is likely to agree to withdraw a majority of its forces by 2014.

The principal conditions where trusteeship is likely to be effective are when (1) the trustee has few, if any, interests beyond stability in the failed state or (2) the interests of the trustee and the average citizen naturally overlap. In such cases, the trustee is willing to back leaders who are close to the median of society, those leaders have incentives to sustain democracy, and aid is likely to flow broadly to the politically active population. Most important, concerned with the well-being of the society, the trustee and the leader have a clear incentive to develop greater capacity. This may be the case in Timor Leste where Australia, constrained by a need for good relations with Indonesia but also interested in natural gas fields in the disputed Timor gap, has largely played the role of neutral arbiter as leader of several international peacekeeping missions. Unfortunately, when the trustee is interested only in stability, it is usually unwilling to bear a high price to build a new state, as suggested by the rapid withdrawal of the United States from Somalia in 1993. The paradox is that trustees willing to intervene in a large-enough and long-enough way to rebuild a legitimate state and enhance state capacity are likely to have some significant interest of their own in the target country. Yet the harder, more extensive, and more costly the statebuilding effort required, the less likely it is to succeed not because of the magnitude of the task but because of the perverse incentives created for all the major actors by the process.

\section{Does Trusteeship Work?}

Do trustees build state capacity? The brief and fairly clear answer is "no." Areas of limited statehood with and without trustees appear to be no different in their levels of state capacity over varying ranges of time. In this section, we present the results of a matched sample of states potentially subject to trusteeship and find no evidence of differences in levels of state capacity. This supports our more political model of trusteeship outlined above.

\section{Research Design}

States that are subject to a trusteeship are likely extreme cases of limited statehood. The reluctance of the international community to authorize a trusteeship over one of its members implies that they will be formed only 
under dire circumstances. Unfortunately for the people living in these severe cases, but fortunately for analysts, not all such states are subject to an international trusteeship, thus allowing us to create a matched sample of similar countries that are subject and not subject to trusteeship. In this quasi-experimental design, we can compare "like-to-like" in evaluating the effect of trusteeship on state capacity.

We operationalize trusteeship by the presence of a United Nations peacekeeping operation (UNPKO). As Fearon and Laitin (2004, 10) suggest, U.N. peacekeeping operations are "a good indicator of... neotrusteeship." Nonetheless, we acknowledge that this is an imperfect measure that includes some ceasefire monitoring missions that would not qualify as full trusteeships and excludes some trusteeships that have not received international approval, like the U.S. interventions in Afghanistan and Iraq. To reduce the heterogeneity in UNPKOs, we limit our analysis to the post-1991 period and the advent of "complex" peacekeeping. Although Chapter 6 peacekeeping operations, negotiated with the parties, may be reasonably assumed to be more legitimate than Chapter 7 missions, which are imposed, there are too few cases of the latter for us to obtain any statistical power. A proper test of our argument would differentiate between these two types of U.N. peacekeeping missions, but the limited number of Chapter 7 cases precludes this strategy. The primary threat to the validity of our test is the inclusion of trustees that have not been authorized by the United Nations in the "control" cases in our matched sample (see below). Including such cases would bias the coefficient on our U.N. trusteeship variable toward zero, producing inadvertently the null result we predict theoretically. To safeguard against this possibility, we exclude all states subject to regional peacekeeping operations or ad hoc multilateral military operations from the set of countries that could be selected as "control" cases.

We follow Lee, Walter-Drop, and Wiesel (2014) in measuring service provision by several indicators of public health, basic infrastructure, and educational attainment, with the exception of using a latent variable model to predict values of state capacity in years earlier than those covered in their data. ${ }^{4}$ Our latent variable model, described in the appendix, ${ }^{5}$ uses a combination of several observed indicators of service provision as defined by Lee, Walter-Drop, and Wiesel for the years they are available to estimate a measure of state capacity throughout the period 1990 to 2010. The predictor variables include: (1) four public health indicators, including the proportion of maternal deaths during pregnancy, infant deaths, neonatal deaths, and deaths under 5 years of age; (2) four indicators of basic infrastructure, including the proportion of households with access to "improved" water resources, per capita electricity consumption, per capita kilometers of roads, and per capita kilometers of rail; and (3) five educational indicators, specifically, the literacy rate, proportion of school-age children that finish grade 5, proportion of enrolled first grade students, 
proportion of primary school students that enroll in secondary school, and the total enrollment of the school-aged population. We exclude the security indicators discussed by Lee, Walter-Drop, and Wissel from our latent variable estimation because we use these variables to create a matched group of treatment and control units (see note 5). The method to estimate the latent variable is similar to others in political science (Trier and Jackman 2008; Schnakenberg and Fariss 2013). The latent variable estimates are easy to interpret and the model is able to incorporate information from a variety of public service provision indicators and a more limited sample of actual observations of state capacity, even those missing observations.

To test for the effect of a UNPKO on service provision, we use a matching procedure to approximate experimental conditions by directly confronting the issue of nonrandom assignment of units to treatment (UNPKO) and control (no UNPKO) groups. Matching creates a group of country-year units in which the UNPKO treatment variable is coded 1 and a control group in which the UNPKO treatment variable is coded 0 . The goal is to produce two groups of country-years that are balanced along a set of theoretically relevant covariates. After matching, we estimate a linear model with robust standard errors.

We use several covariates in the matching algorithm. Ideally, we would identify a treatment and a control unit that are equivalent on each covariate. In practice, however, exact matching is impossible when comparing country-years, which necessitates the use of three different matching algorithms as robustness checks (see note 5). We use measures of political violence as defined by Lee, Walter-Drop, and Wiesel (2014) and demographic characteristics for each country-year unit. The political violence variables are binary variables that capture a minimum violence threshold. We include the presence of a civil war, which is measured 1 if at least 25 battle-related deaths occur in a country-year and 0 otherwise (Gleditsch et al. 2002). We include another binary variable that is coded 1 if at least 25 one-sided deaths (government-perpetrated civilian deaths) occur in a country-year and 0 otherwise (Eck and Hultman 2007). We also include the homicide rate. By matching on these covariates, we are able to then compare county-year treatment and control groups that have experienced statistically similar levels of violence. The demographic variables included are the natural log of real per capita income (constant U.S. dollars) and the natural log of population, measured as the yearly percentage change in population (from Gleditsch 2002). Lastly, we include an interval level democracy variable, Unified Democracy Scale, which is normally distributed with mean 0 and standard deviation 1 (Pemstein et al. 2010). As explained above, we exclude cases that could possibly be considered to have a form of trusteeship not authorized by the United Nations.

We use many of the same covariates in our regression models. Larger homicide rates, one-sided killings, and battle deaths are likely to be posi- 
tively related to the probability of receiving a UNPKO and negatively related to state capacity. Greater democracy, population, and gross domestic product per capita may vary with UNPKOs, but also likely vary with state capacity. Our regression results below are similar with and without these covariates, but we include them here to address concerns with possible omitted variables bias.

\section{Results}

Using our measure of service provision and the matched sample, we assess the effect of trusteeship on state capacity over a time horizon of five years from the start of the U.N. peacekeeping mission. In the appendix (see note 5), we show results from models with other time horizons of 1 to 4 years. The results are consistently insignificant across the models. The results in Table 1 show estimates from a simple linear regression after matching, using each of three matching algorithms. In each model, there is no statistically significant relationship between the trusteeship treatment variable and the provision of public services (for different results with regard to UN Chapter VI Peacekeeping Missions and the cessation of hostilities, see Matanock 2014).

We recognize that heterogeneity exits across the treated units in our sample. That is, there are likely systematic differences in the "dosage" or amount of peacekeeping that a country-year experienced, which may explain some of the variation in the dependent variable. To address this, we selected a subset of treated units, those that received peacekeepers from at least one of the five permanent members of the U.N. Security Council. The results (not shown) are consistently statistically insignificant across these models as well.

Overall, we can find no statistically significant effect of U.N.authorized trusteeship on service provision in states of extremely limited sovereignty, regardless of the measures used, the length of time after the trusteeship begins, or the precise statistical matching technique used. Simply put, international trusteeship has no discernible effect on service provision. These essentially "null" results are troubling, suggesting that U.N.-authorized trustees have not produced better service provision in failed states despite considerable effort toward this end. The results are inconsistent with the naïve approach to statebuilding embodied in current policy, which predicts that trustees will build greater state capacity, which then leads to better service provision, but are consistent with our political model, which predicts little or no relationship between trusteeship and state capacity. We consider the naïve approach effectively disconfirmed by our test. Although there may be many reasons for the lack of a relationship between UNPKOs and service provision, the absence of any statistically significant effect is consistent with our more political model. 
TABLE 1

Estimated Effects of Trusteeship on State Capacity, from Three Models

Nearest Neighbor Matching Algorithm

\begin{tabular}{lccr}
\hline Variables & Coefficients & SE & \multicolumn{1}{c}{$\mathrm{t}$} \\
\hline Intercept & 0.396 & 0.175 & 2.261 \\
Trusteeship (Treatment) & $\mathbf{- 0 . 0 0 9}$ & $\mathbf{0 . 0 1 9}$ & $\mathbf{- 0 . 4 7 2}$ \\
Homicide rate & -0.001 & 0.001 & -0.518 \\
One-sided killings & -0.049 & 0.028 & -1.740 \\
Battle deaths & -0.012 & 0.029 & -0.402 \\
Democracy & 0.015 & 0.022 & 0.672 \\
Population & -0.001 & 0.009 & -0.160 \\
GDP per capita & -0.035 & 0.014 & -2.481 \\
\hline
\end{tabular}

Optimal Matching Algorithm

\begin{tabular}{lccr}
\hline Variables & Coefficients & SE & \multicolumn{1}{c}{$\mathrm{t}$} \\
\hline Intercept & 0.318 & 0.132 & 2.403 \\
Trusteeship (Treatment) & $-\mathbf{0 . 0 0 9}$ & $\mathbf{0 . 0 1 7}$ & $-\mathbf{0 . 5 1 5}$ \\
Homicide rate & 0.000 & 0.001 & 0.244 \\
One-sided killings & -0.044 & 0.021 & -2.071 \\
Battle deaths & 0.004 & 0.038 & 0.115 \\
Democracy & 0.012 & 0.026 & 0.453 \\
Population & 0.003 & 0.009 & 0.358 \\
GDP per capita & -0.033 & 0.012 & -2.824 \\
\hline CEM Matching Algorithm & & & \\
\hline Variables & & & $\mathrm{t}$ \\
\hline Intercept & Coefficients & $\mathrm{SE}$ & $\mathbf{1}$ \\
Trusteeship (Treatment) & 0.376 & 0.248 & $-\mathbf{0 . 9 1 9}$ \\
Homicide rate & $-\mathbf{0 . 0 1 8}$ & $\mathbf{0 . 0 1 9}$ & -0.048 \\
One-sided killings & 0.000 & 0.001 & -2.206 \\
Battle deaths & -0.079 & 0.036 & $\mathbf{1 . 3 5 4}$ \\
Democracy & 0.036 & 0.027 & -0.056 \\
Population & 0.002 & 0.034 & -1.634 \\
GDP per capita & -0.003 & 0.011 & \\
\hline
\end{tabular}

Note: Each treatment effect is estimated in a separate linear regression. The dependent variables are measured as the change from time of treatment to year $t+5$. Alternative models with year $t+1, t+2, t+3, t+4$ are in the appendix (see note 5 ). Note that these results change slightly each time the multiple imputation and matching algorithms are executed. These changes are minor and do not change the substantive interpretation of the results. The appendix and program code contain more details about these procedures.

\section{Dilemmas of Contemporary Trusteeship}

Our political model of statebuilding implies three dilemmas that current practitioners must understand when deciding when and how to 
intervene. By way of summary, and to highlight policy implications, we close with a discussion of these dilemmas.

\section{International Legitimacy Constrains Agency}

Current statebuilding practice emphasizes approval of the trustee by some duly constituted international body, such as the United Nations, the Organization of African Union, or North Atlantic Treaty Organization. International authorization and oversight is intended to deal with two core but conflicting problems of statebuilding in a world of sovereign states. First, international oversight limits the potential for opportunism by selfinterested trustees. This likely facilitates statebuilding. Second, international authorization limits potential trustees from asserting unilaterally rights to involve themselves in the internal affairs of others and limits violations of the principle of Westphalian sovereignty. The result is clear limits on the scope and duration of the trustee's authority. These international limits, however, lead both the trustee and the new state leader to attempt to consolidate political authority in a narrow support coalition as quickly as possible, undermining democracy and economic reform, their legitimacy, and ultimately state capacity. Trustees should request, and international organizations should approve, more expansive mandates of open-ended duration.

\section{Trustees Want Legitimate and Loyal States}

Trustees face two competing goals. As state builders, trustees want to construct states that are perceived as legitimate by their people. At the same time, however, as parties with interests in the failed states, they also want compliant leaders who will carry out their wishes. Except when the policy preferences of the target population and those of the trustee are closely aligned, legitimacy and loyalty are incompatible. Adopting policies preferred by citizens clashes with the desire of the trustee for policies consistent with its aims. When the leader complies with the wishes of the trustee, this alienates the population, which sees its new leader as a puppet of a distant imperialist power. Leaders, in turn, can stay in power only if they are autonomous from their citizens or, at an extreme, authoritarian. The trustee is then locked into providing aid while simultaneously allowing the leader to use those resources to bolster his own political position. Both trustee and leader are, therefore, complicit in a relationship that secures the power of the leader at the cost of democracy, economic reform, and state capacity. The more distant the preferences between the two societies, the more likely the new state created by the trustee will be autocratic, unaccountable, and ultimately illegitimate. Historically, trustees, and especially the United States, have emphasized loyalty over legitimacy when these goals come into conflict (Lake 2010b). There is no easy compromise here. If the international community selects only trustees 
without interests in the target state, those trustees will be unlikely to bear the costs necessary to rebuild capable states over the long term. On balance, trustees should be limited to those states that have only general interests in stability in the region or who have interests closely aligned with those of the median citizen in the failed state.

\section{National Leaders Want to Survive, not Build Capacity or Legitimacy}

State capacity is not a goal for any actor, or at least not a singular goal to which all devote their efforts. For trustees, enhanced capacity is conditioned by the concern over "capacity for what?" Loyalty is typically chosen over capacity alone. For the international community, the desire for capable states is tempered by restrictions on the means by which this result is brought about. For national leaders, survival and the need to consolidate a political support coalition trump capacity. More capable states allow them to extract more for their coalition, but ultimately it is staying in power and solidifying their rule that really matter.

Unless the political preferences of the society coincide with those of the trustee and the trustee is committed to democracy over the long term, the political survival of the leader is enhanced not by building broad-based legitimacy but by diverting aid and other resources to a narrower coalition. Though the members of that coalition will likely regard the leader as legitimate, the population as a whole will see few benefits from backing him relative to likely alternatives. In turn, the population will resist efforts to increase capacity, which would only mean greater extraction of resources from the average citizen and the diversion of those resources to the leader's coalition. State capacity suffers.

Countries with areas of limited statehood suffer from a vicious circle from which it is hard to break loose. Narrow coalitions extract too much from society, increasing both inequality and competition for control of the state. Each successive leader has incentives to act in pretty much the same way, reproducing the vortex that pulls states down. The great promise of trusteeship is that it can break this vicious circle to build new, more capable states. Yet capacity per se is never the goal. Self-interested trustees and the limits on their authority set by the international community bias the statebuilding process to support leaders who form narrow political coalitions. Only when the interests of the trustee and the population coincide can trusteeship indeed loosen the vicious circle.

Although trusteeship may not make the vicious circle worse, it has little to no effect on state capacity. Trusteeship as a solution to the problem of failed states appears to be no solution at all. It should be used sparingly, and then only in the most extreme cases when something must be done to stop the suffering of innocent people. The international community should not expect trusteeship to rebuild capacity, but only to be a temporary fix to limit the violence while other routes to enduring peace are pursued. 


\section{Notes}

1. This liberal approach has been augmented since 2007 by a new focus on counterinsurgency warfare and "winning hearts and minds." See Lake (2010b).

2. For a political model that focuses on trustees, national elites, and subnational elites, see Barnett and Zurcher (2009).

3. On Afghanistan and Iraq, see Allawi (2007), Ghani and Lockhart (2008), Jones (2009), and Rashid (2008).

4. We thank the authors for sharing these data.

5. The appendix, the data, and $\mathrm{R}$ code necessary to replicate the procedures reported are publicly available at a Dataverse archive here: http:// www.hdl.handle.net/1902.1/22441

\section{References}

Acemoglu, Daron, and James Robinson. 2012. Why Nations Fail: The Origins of Power, Prosperity, and Poverty. New York: Crown Business.

Allawi, Ali A. 2007. The Occupation of Iraq: Winning the War, Losing the Peace. New Haven, CT: Yale University Press.

Bain, William. 2003. Between Anarchy and Society: Trusteeship and the Obligations of Power. New York: Oxford University Press.

Barbara, Julien. 2008. "Rethinking Neo-Liberal State Building: Building PostConflict Development States." Development in Practice 18 (3): 307-318.

Barnett, Michael, and Christoph Zurcher. 2009. "The Peacebuilder's Contract: How External Statebuilding Reinforces Weak Statehood." In The Dilemmas of Statebuilding: Confronting the Contradictions of Postwar Peace Operations, ed. R. Paris and T. D. Sisk. New York: Routledge.

Bueno de Mesquita, Bruce, Alastair Smith, Randolph M. Siverson, and James D. Morrow. 2003. The Logic of Political Survival. Cambridge, MA: MIT Press.

Chesterman, Simon. 2004. You, the People: The United Nations, Transitional Administration, and State-Building. New York: Oxford University Press.

Eck, Kristine, and Lisa Hultman. 2007. "One-Sided Violence Against Civilians in War: Insights from New Fatality Data." Journal of Peace Research 44 (2): 233-246.

Fearon, James D., and David D. Laitin. 2004. "Neotrusteeship and the Problem of Weak States." International Security 28 (4): 5-43.

Ghani, Ashraf, and Clare Lockhart. 2008. Fixing Failed States: A Framework for Rebuilding a Fractured World. New York: Oxford University Press.

Gleditsch, Kristian S. 2002. "Expanded Trade and GDP Data." Journal of Conflict Resolution 46: 712-724.

Gleditsch, Nils Petter, Peter Wallenstten, Mikael Eriksson, Margareta Sollenberg, and Havard Strand. 2002. "Armed Conflict 1946-2001: A New Dataset." Journal of Peace Research 39 (5): 615-637.

Goldstone, Jack A., Ted Robert Gurr, Barbara Harff, and Marc A. Levy. 2000. State Failure Task Force Report: Phase III Findings. McLean, VA: Science Applications International Corporation.

Jackson, Robert H. 1990. Quasi-States: Sovereignty, International Relations and the Third World. New York: Cambridge University Press.

Jones, Seth G. 2009. In the Graveyard of Empires: America's War in Afghanistan. New York: W. W. Norton.

Krasner, Stephen D. 1999. Sovereignty: Organized Hypocrisy. Princeton, NJ: Princeton University Press.

- 2004. "Sharing Sovereignty: New Institutions for Collapsed and Failing States." International Security 29 (2): 85-120. 
Krasner, Stephen D., and Thomas Risse. 2014. "External Actors, State-Building, and Service Provision in Areas of Limited Statehood: Introduction." Governance 27 (4): 545-567.

Lake, David A. 2010a. "Building Legitimate States after Civil Wars." In Strengthening Peace in Post-Civil War States: Transforming Spoilers into Stakeholders, ed. C. Hartzell and M. Hoddie. Chicago, IL: University of Chicago Press.

- 2010b. "The Practice and Theory of U.S. Statebuilding." Journal and Intervention and Statebuilding 4 (3): 257-284.

Lee, Melissa, Gregor Walter-Drop, and John Wiesel. 2014. "Taking the State (Back) Out? Statehood and the Delivery of Collective Goods." Governance 27 (4): 635654.

Matanock, Aila M. 2014. “Governance Delegation Agreements: Shared Sovereignty as a Substitute for Limited Statehood." Governance 27 (4): 589-612.

Paris, Roland. 2004. At War's End: Building Peace After Civil Conflict. New York: Cambridge University Press.

Paris, Roland, and Timothy D. Sisk, ed. 2009. The Dilemmas of Statebuilding: Confronting the Contradictions of Postwar Peace Operations. New York: Routledge.

Parker, Tom. 2003. The Ultimate Intervention: Revitalizing the UN Trusteeship Council for the 21st Century. Sandvika, Norway: Center for European and Asian Studies, Norwegian School of Management.

Pemstein, Daniel, Stephen A. Meserve, and James Melton. 2010. "Democratic Compromise: A Latent Variable Analysis of Ten Measures of Regime Type." Political Analysis 18 (4): 426-449.

Rashid, Ahmed. 2008. Descent into Chaos: The United States and the Failure of Nation Building in Paksitan, Afghanistan, and Central Asia. New York: Viking.

Rotberg, Robert I., ed. 2004. When States Fail: Causes and Consequences. Princeton, NJ: Princeton University Press.

Schnakenberg, Keith E., and Christopher J. Fariss. 2013. "Dynamic Patterns of Human Rights Practices." Political Science Research and Methods. Advance online publication. DOI:10.1017/psrm.2013.15

Sending, Ole Jacob. 2009. "Why Peacebuilders Fail to Secure Ownership and Be Sensitive to Context." Security in Practice (NUPI Working Paper 755). Oslo, Norway, Norwegian Institute of International Affairs, Department of Security and Conflict Management.

Spruyt, Hendrik. 1994. The Sovereign State and Its Competitors: An Analysis of Systems Change. Princeton, NJ: Princeton University Press.

Tilly, Charles. 1990. Coercion, Capital, and European States, AD 990-1990. Cambridge, MA: Basil Blackwell.

Trier, Shawn, and Simon Jackman. 2008. "Democracy as a Latent Variable." American Journal of Political Science 52 (1): 201-217.

Walter, Barbara F. 1997. "The Critical Barrier to Civil War Settlement." International Organization 51 (3): 335-364.

Weber, Max. 1948. From Max Weber. New York: Galaxy.

. 1978. Economy and Society. Berkeley, CA: University of California Press. 